This article was downloaded by: [Texas Technology University]

On: 16 December 2008

Access details: Access Details: [subscription number 788736273]

Publisher Taylor \& Francis

Informa Ltd Registered in England and Wales Registered Number: 1072954 Registered office: Mortimer House, 37-41 Mortimer Street, London W1T 3JH, UK

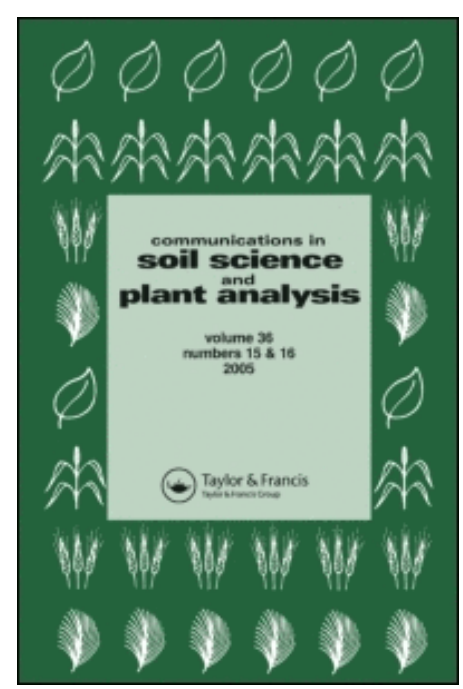

Communications in Soil Science and Plant Analysis

Publication details, including instructions for authors and subscription information:

http://www.informaworld.com/smpp/title content=t713597241

\title{
VARIABILITY OF COTTON YIELD AND QUALITY
}

Michael K. Elms a; Cary J. Green a; Phillip N. Johnson ${ }^{\text {b }}$

a Department of Plant and Soil Science, Texas Tech University, Lubbock, TX, U.S.A. ${ }^{b}$ Department of Agricultural and Applied Economics, Texas Tech University, Lubbock, TX, U.S.A.

Online Publication Date: 31 March 2001

To cite this Article Elms, Michael K., Green, Cary J. and Johnson, Phillip N.(2001)'VARIABILITY OF COTTON YIELD AND QUALITY',Communications in Soil Science and Plant Analysis,32:3,351 - 368

To link to this Article: DOI: $10.1081 /$ CSS-100103012

URL: http://dx.doi.org/10.1081/CSS-100103012

\section{PLEASE SCROLL DOWN FOR ARTICLE}

\footnotetext{
Full terms and conditions of use: http://www.informaworld.com/terms-and-conditions-of-access.pdf

This article may be used for research, teaching and private study purposes. Any substantial or systematic reproduction, re-distribution, re-selling, loan or sub-licensing, systematic supply or distribution in any form to anyone is expressly forbidden.

The publisher does not give any warranty express or implied or make any representation that the contents will be complete or accurate or up to date. The accuracy of any instructions, formulae and drug doses should be independently verified with primary sources. The publisher shall not be liable for any loss, actions, claims, proceedings, demand or costs or damages whatsoever or howsoever caused arising directly or indirectly in connection with or arising out of the use of this material.
} 


\title{
VARIABILITY OF COTTON YIELD AND QUALITY
}

\author{
Michael K. Elms, ${ }^{1}$ Cary J. Green, ${ }^{1, *}$ and Phillip N. \\ Johnson ${ }^{2}$ \\ ${ }^{1}$ Department of Plant and Soil Science, Texas Tech \\ University, Lubbock, TX 79409-2122 \\ ${ }^{2}$ Department of Agricultural and Applied Economics, \\ Texas Tech University, Lubbock, TX 79409-2122
}

\begin{abstract}
Precision agriculture technologies offer an opportunity to vary production inputs within a field. Variable rate application offers the potential to increase production efficiency and minimize potential adverse environmental effects of agricultural chemicals. As an initial step in the development of precision agriculture technologies for cotton, studies are needed to document variability of cotton. The primary objective of this study was to document variability of yield and quality of irrigated cotton within and across three growing seasons. This study was conducted on a 5.3 ha irrigated field located at the Erskine Research Farm at Texas Tech University, Lubbock, TX. The crop was grown under a conventional tillage system with a $1.0 \mathrm{~m}$ row spacing. With the exception of sample collection, the field was managed traditionally with respect to production inputs. A grid system (57 points) was established on $30.5 \mathrm{~m}$ (approximately $0.1 \mathrm{ha}$ ) intervals. Production of fruiting
\end{abstract}

* Corresponding author. E-mail: cary.green@ttu.edu 
sites, fruit retention, lint yield, fiber length, strength, micronaire, and gross revenue were estimated for each grid point. Soil chemical and physical properties were also determined for each grid point. Highest variability was observed for lint yield and production of fruiting sites, and lowest variability was observed for lint quality parameters. Yield was correlated to production of fruiting sites each season. Nitrate concentrations were highly variable, and yield was negatively correlated to nitrogen $(\mathrm{N})$ in 1997 . This suggests that variable application of $\mathrm{N}$ may be a viable management option in the future. Yield was positively correlated to calcium (Ca), pH, and CEC in 1997. Yield variability was correlated across growing seasons. Gross revenues were quite variable, due primarily to yield variability.

\section{INTRODUCTION}

Cotton (Gossypium hirsutum L.) yield is influenced by many factors. Climatic factors such as moisture availability, length of growing season, and temperature extremes affect yield. Other sources of variability include soil type, soil moisture, $\mathrm{pH}$, fertility levels, organic matter, weed pressure, insect pressure, growth regulators, crop termination, and wildlife damage $(1,2)$. Typically, yield variations occur within a field even though climate, cultural practices, and timing of irrigation are uniform (3).

Oosterhuis et al. (4) evaluated plant-water status, canopy temperature, and soil variability in cotton growth variability experiments. Soil variability was the main cause of observed growth differences that generally occurred in the middle of the season at peak canopy photosynthesis when demand for nutrients and water was highest (4).

Fiber quality may also vary within a field. The quality of a cotton plant (which results in fiber development) is directly affected by the quality of the growth environment (5). Grimes et al. (6) stated that fiber length, micronaire, strength, and elongation were influenced more by water supply than by $\mathrm{N}$-supply. Bradow et al. (7) stated that in their studies in 1992 and 1993, rainfall was normal and did not significantly affect cotton fiber maturation rates. Another important environmental influence on fiber maturity is heat unit accumulation during the period between floral anthesis and harvest (7). Nitrogen applications are reported to increase fiber length, and applications of potassium $(\mathrm{K})$ are reported to increase micronaire (8). Cassman et al. (9) reported increased fiber length and secondary wall thickness (measured as a micronaire index) obtained from plants that received fertilizer K. 
Despite many sources of variability, entire fields generally have been managed as a single unit (2). However, yield variability within a field suggests that variable application of inputs may be appropriate. Precision agriculture technologies give the producer an opportunity to vary production inputs within a field. Variable rate application offers the potential to increase production efficiency and minimize potential adverse environmental effects of agricultural chemicals.

Uniformly fertilizing a field where soil fertility levels vary within the field, for example, potentially leads to overfertilization of some areas (10). Similarly, some areas may receive less fertilizer than is needed. Fertilizer resources may be better managed by applying variable rates across the landscape to better match patterns in soil fertility (10). Additionally, by knowing the areas of the field that consistently produce the highest and lowest yields, inputs such as seed, pesticides, and growth regulators can be varied to potentially maximize production efficiency while minimizing negative environmental impact (2). Therefore, precision agriculture offers potential economic and environmental benefits. Indeed, growers, industry, universities, and government agencies see opportunities with precision agriculture for developing more efficient agricultural systems as well as for improving land stewardship and environmental concerns (11).

Relative to grain production systems, however, application of precision agriculture technology to cotton production is lagging. Very little data exist that document yield variability of cotton. Years of cotton yield variability data, soil maps, site-specific soil tests, and identification of other variables that could affect yields are needed to make informed management decisions for small areas within a field rather than making decisions based on the field as a whole (2). Furthermore, it must be demonstrated that the precision agriculture technology is cost effective for cotton production.

The primary objective of this study was to evaluate in-field variability of yield and quality of irrigated cotton. Variability in economic value was estimated. This variability was evaluated within each growing season and across growing seasons. Relationships between soil and plant parameters also were evaluated.

\section{MATERIALS AND METHODS}

This study was conducted on a 5.3 ha field located at the Erskine Research Farm at Texas Tech University, Lubbock, TX. The predominant soil type present was Amarillo fine, sandy loam (fine-loamy, mixed superactive, thermic Aridic Paleustalfs). Acuff loam (fine-loamy, mixed, thermic Aridic Paleustolls) was also present. Irrigation was supplied by a low energy precision application (LEPA) center pivot irrigation system. The crop was grown under a conventional tillage system with a $1.0 \mathrm{~m}$ row spacing. With the exception of sample collection, the field was managed traditionally with respect to production inputs. 


\section{Growing Season}

Cotton (HS-26) was planted on 22 May 1996 at approximately 160600 seeds/ha. The field was fertilized with $90 \mathrm{~kg} \mathrm{~N} / \mathrm{ha}, 25 \mathrm{~kg} \mathrm{P} / \mathrm{ha}, 0.6 \mathrm{~kg} \mathrm{Zn} / \mathrm{ha}$, and $0.28 \mathrm{~kg} \mathrm{Cu} / \mathrm{ha}$. From 1 May 1996 until 1 November 1996, the site received $36.3 \mathrm{~cm}$ of rainfall. An additional $21.8 \mathrm{~cm}$ of water was supplied via irrigation to provide a total of approximately $58 \mathrm{~cm}$ of water. Normal rainfall for the same period is approximately $37 \mathrm{~cm}$.

A grid system was established on $30.5 \mathrm{~m}$ (approximately $0.1 \mathrm{ha}$ ) intervals. Fifty-seven grid points were located inside the irrigated portion of the field. Four plants were collected for determination of production of fruiting sites and fruit retention (12). Yield data were collected at each sampling point (i.e., the center of each grid cell) by harvesting all bolls within an area of $1.3 \mathrm{~m} \times 3.0 \mathrm{~m}$ ( 3 rows * $1.3 \mathrm{~m})$. The harvested bolls were ginned in a test plot gin (20 saws) made by Dennis Manufacturing in Athens, TX. The lint obtained from this gin had some seed contamination, and the yields calculated for the plots seemed too high. The high yields were assumed to be due to seed contamination in the lint. Therefore, the plot yields were adjusted to reflect the actual yield (as determined by harvesting the entire field) by multiplying this yield by percentage yield at each sampling point. Percentage yield at each sampling point was determined by expressing yield at each sampling point as a percentage of the average yield obtained from the grid sampling system. A subsample of lint from each yield sample was sent to the International Textile Center in Lubbock, TX, for HVI classing (13).

\section{Growing Season}

Soil samples were taken on 12 January 1997 at the center of each grid cell in the area where the bolls were harvested. Within each grid cell, 9 samples were collected from 0 to $15 \mathrm{~cm}$ and from 15 to $30 \mathrm{~cm}$. At each depth, the 9 subsamples were composited. The composited samples were analyzed by using the following procedures: organic matter (14), pH, phosphorous (Bray P-1 and Olsen) (15), potassium, calcium, cation exchange capacity (16), and zinc, manganese, iron, and copper (17), nitrate-nitrogen (18) and particle size (19).

Cotton (HS-26) was planted on 23 May 1997 at approximately 160600 seeds/ha. The field was fertilized uniformly with $135 \mathrm{Kg} \mathrm{N} / \mathrm{ha}, 29 \mathrm{Kg} \mathrm{P} / \mathrm{ha}$, and $0.6 \mathrm{Kg} \mathrm{Zn/ha.} \mathrm{From} 1$ January 1997 until 31 October 1997, the site received $48.3 \mathrm{~cm}$ of rainfall. An additional $20.3 \mathrm{~cm}$ of water was supplied via irrigation to provide a total of approximately $69 \mathrm{~cm}$ of water.

Yield data were collected as described for the 1996 growing season. The samples were collected at the same locations as in 1996. Eight plants were collected for determination of production of fruiting sites and fruit retention (12). 
Due to problems associated with the gin used in 1996, a different gin was used in 1997. The gin used to separate the seed from the lint in 1997 was a 10 saw gin made by Continental Manufacturing in Prattville, AL. Lint quality parameters were determined as described previously.

\section{Growing Season}

Cotton (HS-26) was planted 19 May 1998 at approximately 160600 seeds / ha. The field was fertilized uniformly twice. The first application on 16 June 1998, supplied $66.9 \mathrm{Kg} \mathrm{N} /$ ha and 44.6 Kg P/ha. The second application on 16 July 1998, supplied 66.9 Kg N/ha. From 1 January 1998 until 30 November 1998, the site received $22.1 \mathrm{~cm}$ of rain. An additional $27.9 \mathrm{~cm}$ of water was supplied via irrigation to provide a total of approximately $50 \mathrm{~cm}$ of water.

Yield data were collected as described for the 1996 and 1997 growing seasons. Eight plants were collected for determination of production of fruiting sites and fruit retention (12). The gin used was the same gin as that used in 1997. Lint quality parameters were determined as described previously.

\section{Data Analyses}

No formal treatments were applied in the study reported here. The purpose of the data analysis procedures was to evaluate variability within a growing season and to evaluate the consistency of the variability among growing seasons. To develop an index of variability within a growing season, coefficients of variation (CVs) were calculated for the parameters measured in this study. CVs express the standard deviation of a data set as a percentage of the mean of the data set (20). Therefore, data sets with different means (i.e., data sets from different years in this study) can be compared in terms of relative variability. Data sets with a CV less than 5\% were denoted "low variability." Data sets with a CV between 5 and $15 \%$ were denoted "moderate variability." Data sets with a CV above $15 \%$ were denoted "high variability." Additionally, "range in variability" was calculated by dividing the maximum value of a data set by the minimum value of a data set.

To further evaluate the consistency of yield across growing seasons, yield was divided into quartiles each year. Change in quartile ranking was then determined by subtracting the quartile ranking for each point in one year from its quartile ranking for the year of comparison. Histograms of change in quartile rankings were then developed.

To evaluate the consistency of the variation among growing seasons, correlation analyses were performed. Correlation analysis is appropriate when evaluating relationships between variables without the assumption of dependency of 
one variable upon another variable (21). Selection of the appropriate correlation procedure is dependent upon the distribution of the data. Distribution of data was tested using the Kolmorgorov-Smirnov test for normal distribution (22). For normally distributed data, the Pearson Product Moment correlation procedure is appropriate; for nonnormal distributed data, the Spearman Rank Order correlation procedure is appropriate (20). Since correlation analyses in this study often compared normal and nonnormal data sets, the Spearman Rank Order procedure was used in this study. To visually present the yield data, frequency distribution histograms were developed (23).

Gross cotton lint revenues were estimated for each sampling point for 1996, 1997, and 1998. Price estimates were obtained using the 1997 Daily Price Estimation System (DPES) pricing equation (24). The DPES is a computerized, econometrically-based price analysis system that evaluates cotton sales and estimates quality premiums and discounts observed in the market (24). Lint quality factors used in the pricing equation are based on HVI grading standards. The 1997 DPES equation was used to estimate prices for all years; therefore, price differences between years were solely based on quality differences. The relative contribution of price and yield to gross revenue was determined by expressing the sums of squares attributed to price and yield as a percentage of the total model sums of squares as determined by analysis of variance using the GLM procedure (25).

\section{RESULTS AND DISCUSSION}

This study was conducted over three growing seasons. Growing season rainfall was near normal for the 1996 growing season. Favorable growing conditions and relatively high moisture availability characterized the 1997 growing season. An extreme drought occurred during 1998.

Production of fruiting sites exhibited a 2.4 to 2.6 range in variability during the three growing seasons (Table 1). Average number of fruiting sites per plant ranged from 20.4 to 25.8. The CVs for fruiting sites ranged from 19.7 to 20.3 . Production of fruiting sites is influenced by available water supply $(26,27)$ and by nutrient supply $(27,28)$.

Fruit retention exhibited a 1.6 to 3.5 range in variability during the three growing seasons (Table 1). Average fruit retention ranged from 24.8 to $37.4 \%$. The CVs for fruit retention ranged from 10.5 to $19.7 \%$. Fruit retention is influenced by many factors in the growing environment such as nutrients (especially nitrogen), nighttime temperature, rain (at flower initiation), and cloudy weather (27, 29, 30). Guinn and Mauney (31) stated that water deficits decreased fruit retention percentage. High boll weevil populations were observed in the study area. Therefore, fruit retention may have been affected by boll weevil pressure during this study. 


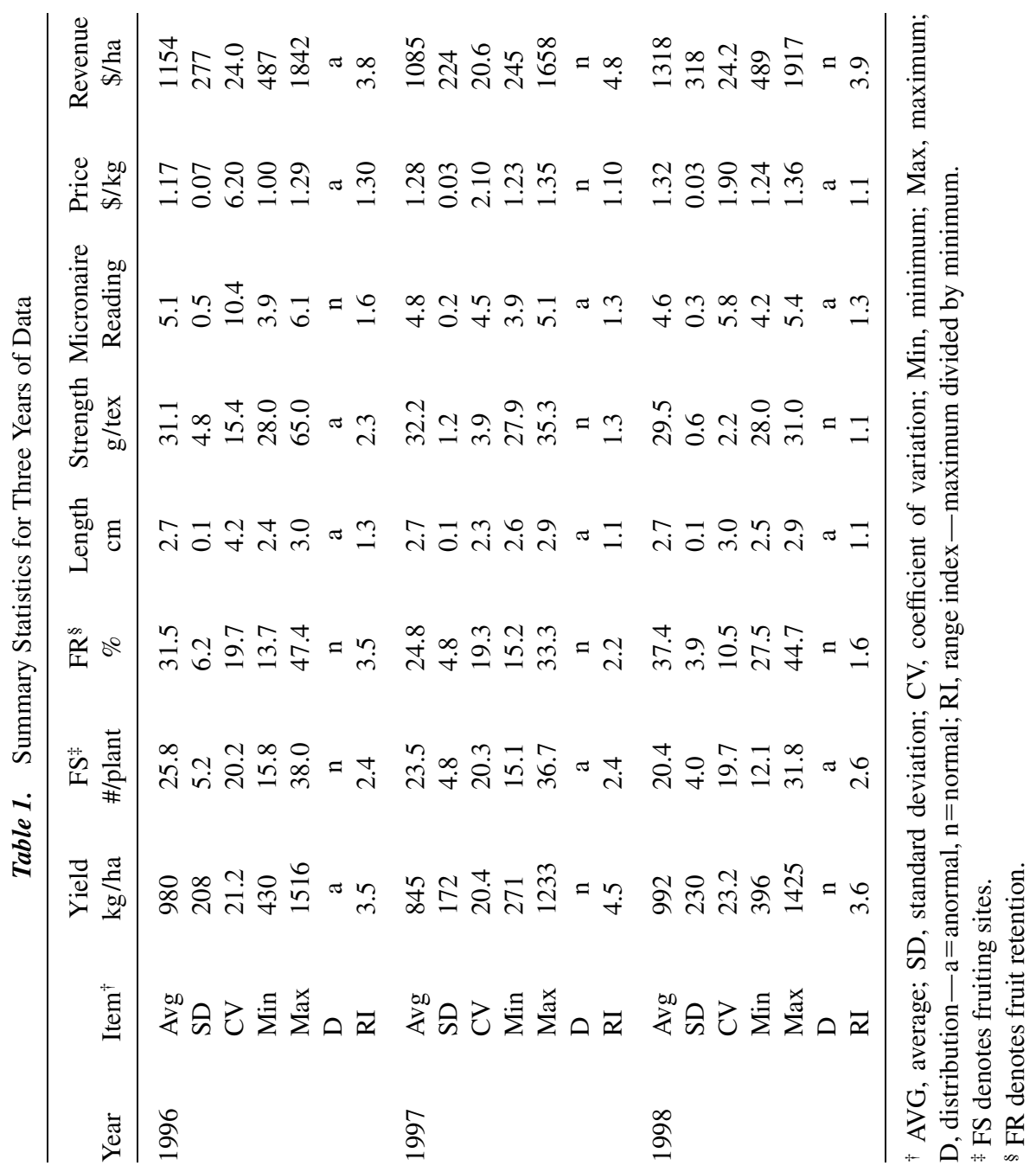


Fiber length exhibited a 1.1 to 1.3 range in variability during the three growing seasons (Table 1). Fiber length averaged $2.7 \mathrm{~cm}$ in each year. The CVs for fiber length ranged from 2.3 to $4.2 \%$. Fiber length is primarily determined by variety but is also influenced by temperature, water, and nutrient stresses (13). Furthermore, fiber length is affected by daytime and nighttime temperature $(32,33)$.

Fiber strength exhibited a 1.1 to 2.3 range in variability during the three growing seasons (Table 1). Average fiber strength ranged from 29.5 to $32.2 \mathrm{~g} / \mathrm{tex}$ in each year. The CVs for fiber strength ranged from 2.2 to $4.8 \%$. Fiber micronaire exhibited a 1.3 to 1.6 range in variability during the three growing seasons (Table 1). Average fiber micronaire ranged from 4.6 to 5.1 in each year. The CVs for fiber micronaire ranged from 4.5 to $10.4 \%$. Lower micronaire values are associated with immature fibers (34).

Lint yield exhibited a 3.5 to 4.5 range in variability during the three growing seasons, and average yields ranged from 845 to $992 \mathrm{~kg} / \mathrm{ha}$. (Table 1). Yield histograms for each growing season are shown in Figure 1. Ping and Green (35) reported ranges in lint yield from 673 to $1467 \mathrm{~kg} / \mathrm{ha}$ and 640 to $1450 \mathrm{~kg} / \mathrm{ha}$ for two 49 ha center pivot irrigated cotton fields in West Texas. Pennington (36) reported ranges in lint yield from $1008-2128 \mathrm{~kg} / \mathrm{ha}$ in the Mississippi Delta. The CVs for yield ranged from 20 to $23 \%$ (Table 1). Ping and Green (35) reported CVs of 19 and $20 \%$ for yield on two 49 ha center pivot irrigated cotton fields. Johnson et al. (37) reported CVs of $52 \%$ for cotton grown in South Carolina. Johnson et al. (38) reported CVs of 33\% for cotton grown in Louisiana. Karlen et al. (39) reported CVs of 17 to $28 \%$ for corn, $16 \%$ for wheat, and $27 \%$ for grain sorghum. Therefore, the variation in cotton yield observed in this study appears comparable to that observed for other common agricultural crops.

Even though the average yields varied from year to year, there were significant correlations between yield among years (Table 2). This suggests that relative productivity at each grid point remained fairly constant, and this relationship is further illustrated by quartile comparisons. Comparing 1996 to 1997, yield at approximately $40 \%$ of the sampling points remained in the same quartile ranking both seasons, and yield at approximately $49 \%$ of the sampling points changed by only one quartile ranking (Figure 2). Yield at approximately $26 \%$ of the points increased in quartile ranking, and yield at approximately $33 \%$ of the points decreased in quartile ranking. Comparing 1997 to 1998, yield at approximately 46\% of the sampling points remained in the same quartile ranking both seasons, and yield at approximately $44 \%$ of the sampling points changed by only one quartile ranking (Figure 2). Yield at approximately $28 \%$ of the points increased in quartile ranking, and yield at approximately $26 \%$ of the points decreased in quartile ranking. Comparing 1996 to 1998, yield at approximately 54\% of the sampling points remained in the same quartile ranking both seasons, and yield at approximately $25 \%$ of the sampling points changed by only one quartile ranking (Figure 2). 

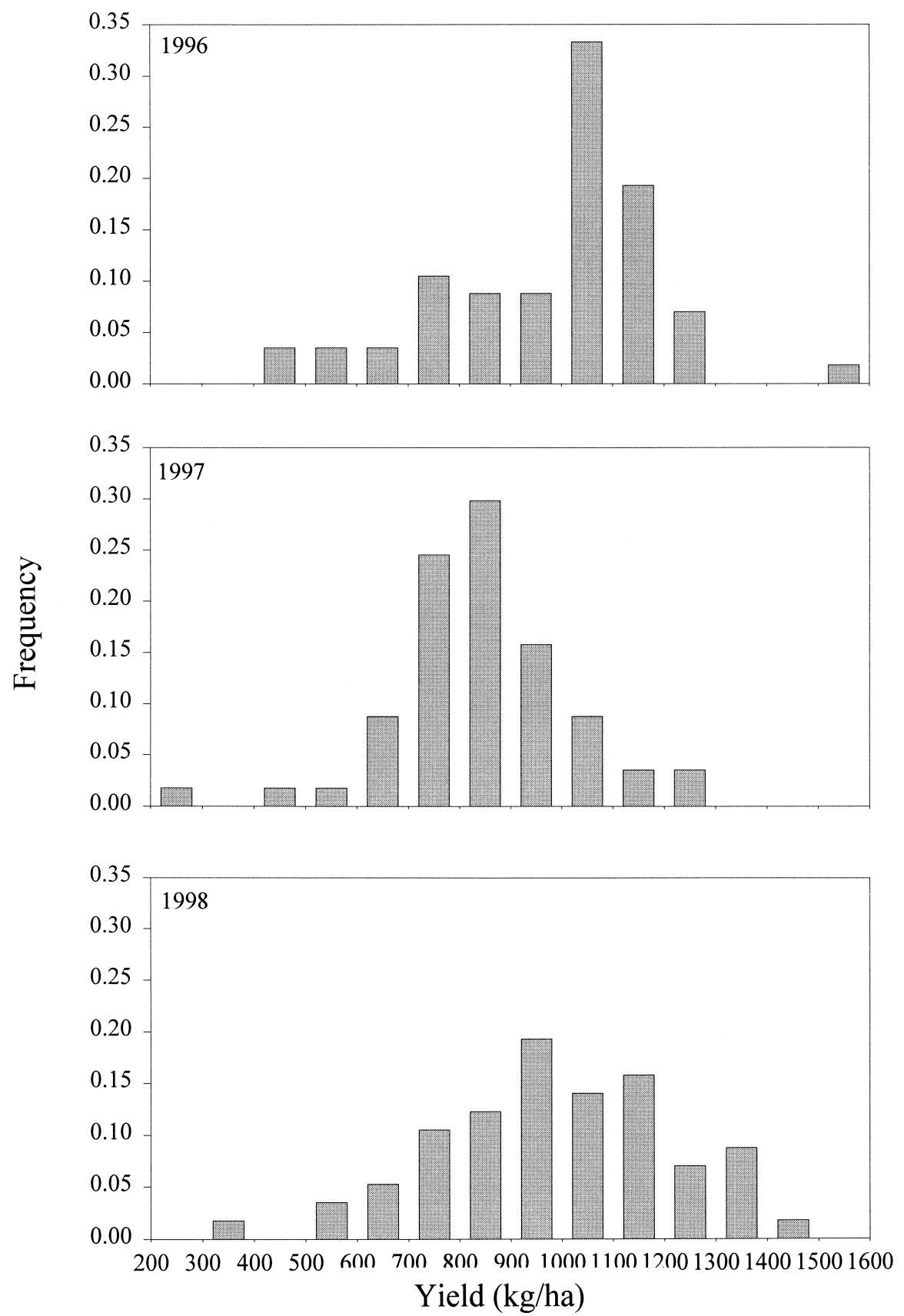

Figure 1. Yield histograms for three growing seasons. 
Table 2. Correlation Coefficients for Plant Parameters Among Growing Seasons

\begin{tabular}{lccc}
\hline & 1996 vs. 1997 & 1997 vs. 1998 & 1996 vs. 1998 \\
\hline Yield & 0.63 & 0.62 & 0.58 \\
Fruiting sites & 0.29 & $\mathrm{~ns}^{\dagger}$ & $\mathrm{ns}$ \\
Fruit retention percentage & $\mathrm{ns}$ & 0.41 & $\mathrm{~ns}$ \\
Fiber length & 0.48 & 0.53 & 0.51 \\
Fiber strength & $\mathrm{ns}$ & $\mathrm{ns}$ & $\mathrm{ns}$ \\
Fiber micronaire & $\mathrm{ns}$ & $\mathrm{ns}$ & 0.48 \\
\hline
\end{tabular}

${ }^{\dagger} \mathrm{ns}=$ not significant at the 0.05 level based on the Spearman Rank Order Correlation analysis.

Yield at approximately $23 \%$ of the points increased in quartile ranking, and yield at approximately $23 \%$ of the points decreased in quartile ranking.

Lint yield was positively correlated to fruiting sites in each of the three growing seasons (Table 3). Yield was positively correlated to fruit retention in 1996 but not in the other two growing seasons (Table 3). Therefore, variability in production of fruiting sites was an important factor influencing variability in cotton yield under the conditions of this study.

Yield was positively correlated to fiber length in each of the three growing seasons (Table 3). Furthermore, fiber length was correlated across the growing seasons (Table 2). Since the same variety was planted in each of the three years of this study, and since fiber length was correlated across the growing seasons (Table 2), it is likely that cotton variety was a major factor influencing fiber length in this study.

Yield was negatively correlated with micronaire during the 1996 and 1998 growing seasons (Table 3 ). Furthermore, micronaire was negatively correlated with number of fruiting sites and fiber length in 1996 and 1998 (Table 3). Fiber micronaire was negatively correlated to fruit retention and fiber strength in 1997 (Table 3).

During 1996 and 1998, the negative correlation of fiber micronaire with yield, fruiting sites, and length suggests that immature bolls were present at harvest. While these immature bolls contributed to lint yield, the increased yield was due in part to immature fiber with low micronaire. Therefore, even though lint yield increased, micronaire decreased. Furthermore, the negative correlation between micronaire and fruiting sites suggests that as production of fruiting sites increased (i.e., more bolls were set), more immature bolls were present at harvest.

The number of bolls present on a plant is determined by the product of fruiting sites and fruit retention. This product was 8.3, 6.0, and 7.4 bolls per plant for the 1996, 1997, and 1998 growing seasons. Therefore, more bolls per plant tended to be present during the 1996 and 1998 growing seasons than during the 

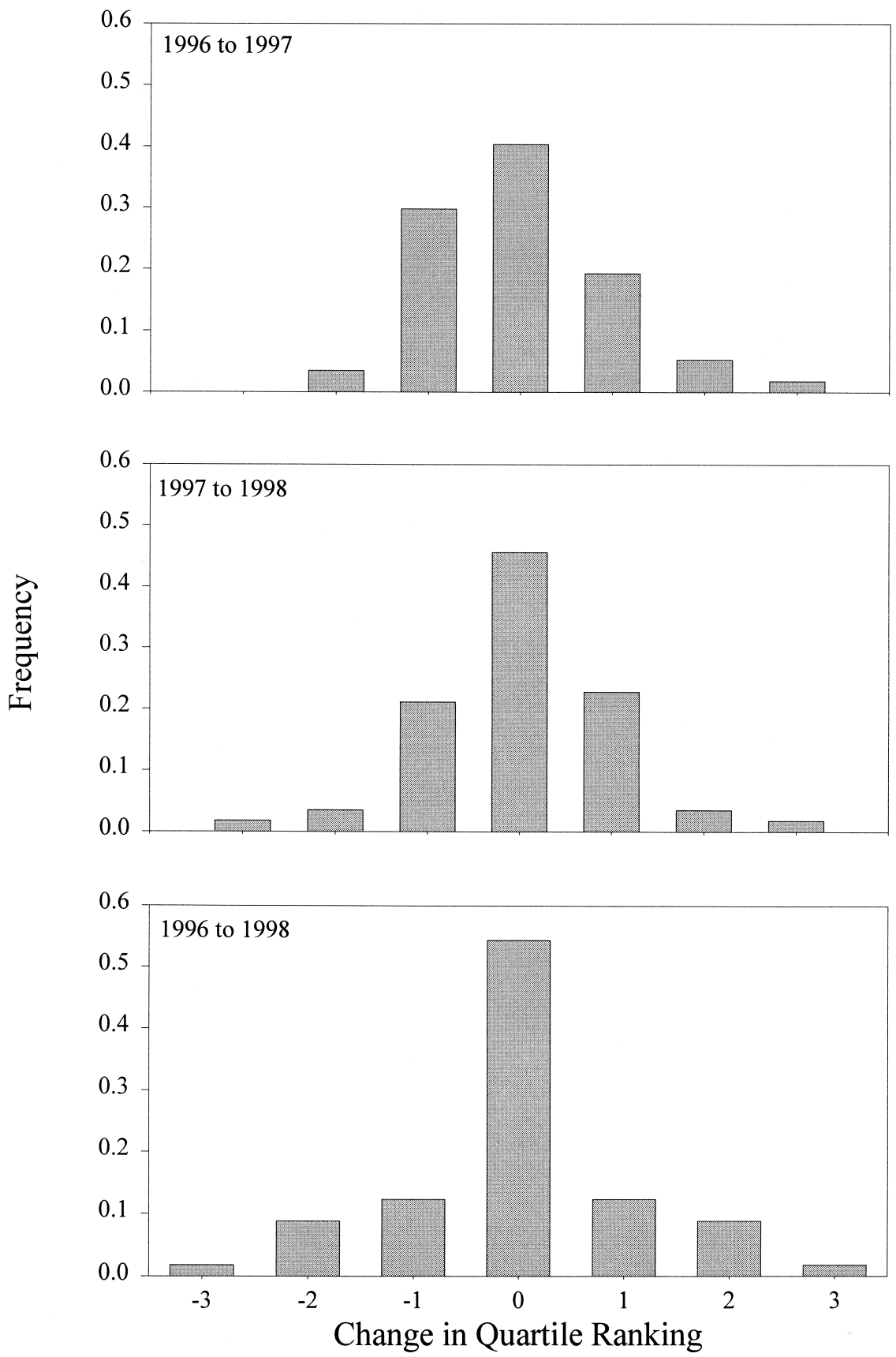

Figure 2. Change in quartile rankings. 
ORDER

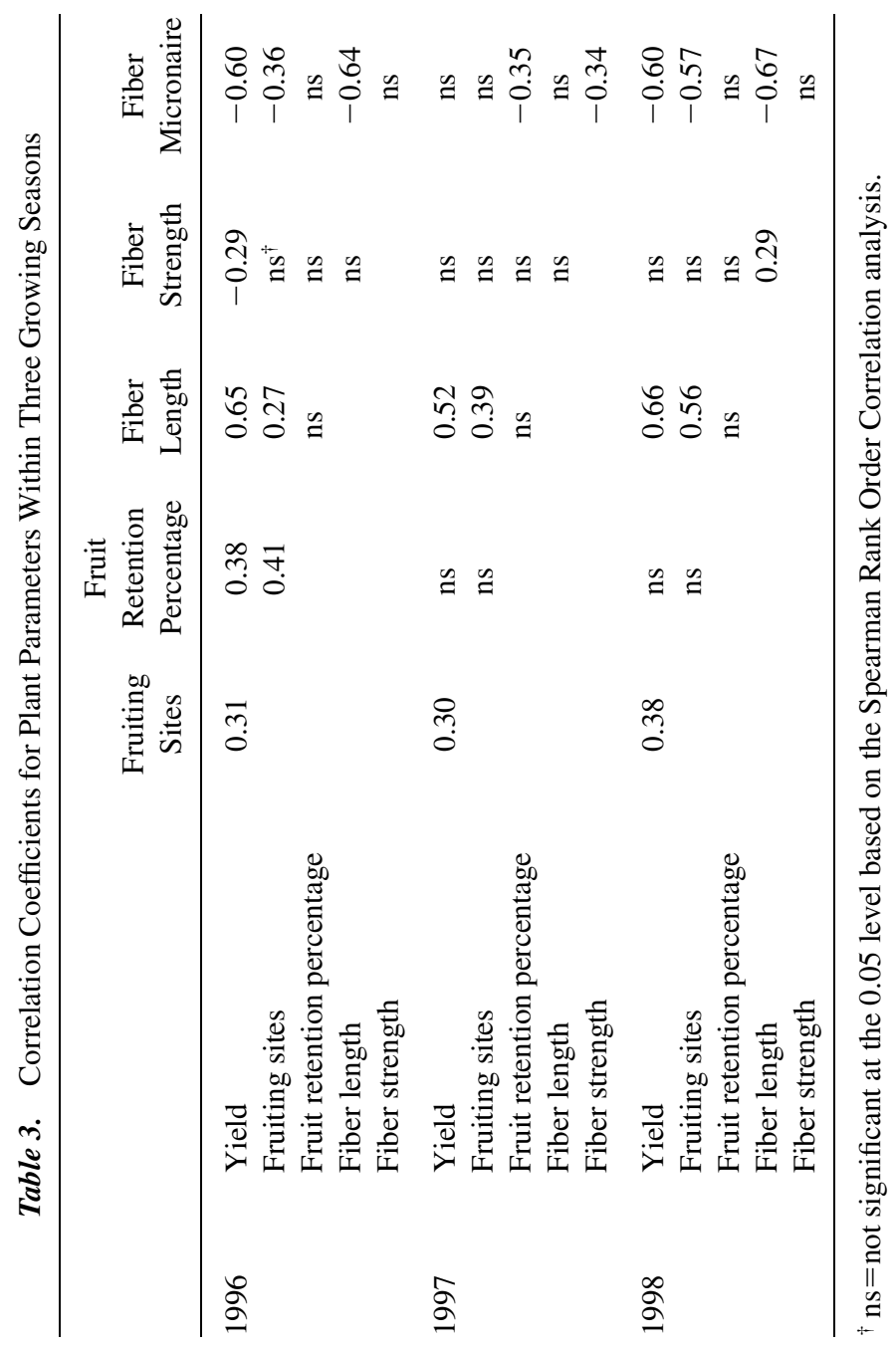


1997 growing season. The relationships between yield, fruiting sites, fruit retention, length, strength, and micronaire suggests that while more fruit per plant were present during 1996 and 1998, this fruit was less mature at harvest than the fruit produced in 1997.

Based on the 1997 DPES price equation (24), price exhibited a 1.1 to 1.3 range in variability during the three growing seasons (Table 1). Even though the absolute values for price of the hand harvested lint samples may not represent accurately those of machine harvested samples, these data can be used as a comparative indicator of variability of quality-induced changes in price. Average price ranged from 1.17 to $1.32 \$ / \mathrm{kg}$. The CVs for price ranged from 2.1 to $6.2 \%$. Gross revenue is the product of yield and price at each given point.

Gross revenues exhibited a 3.8 to 4.8 range in variability during the three growing seasons (Table 1). Average gross revenues ranged from 1084 to 1318 \$/ ha. The CVs for gross revenue ranged from 20.6 to $24.2 \%$. Gross revenues are influenced by yield and quality (price) of lint. Analyses of variance showed that yield accounted for at least $95 \%$ of the observed variability in gross revenue, and that price accounted for less than $5 \%$ of the observed variability in revenue.

Soil samples were collected in 1997, and a summary of measured soil properties is shown in Table 4. The highest variability was observed for zinc $(\mathrm{CV}=50.9)$ and nitrate $(\mathrm{CV}=54.4)$, and the lowest variability was observed for soil $\mathrm{pH}(\mathrm{CV}=2.3)$ and sand percentage $(\mathrm{CV}=3.0)$. Only four soil parameters measured in this study were correlated with lint yield in 1997 (Table 4). Nitrate was negatively correlated with yield. Reductions in cotton yield at high levels of available $\mathrm{N}$ can be attributed to excessive vegetative growth, and increased disease and insect pressure, and delayed maturity (1). Due to the negative effects of high $\mathrm{N}$ on yield and the high variability of nitrate observed in this study, variable application of $\mathrm{N}$ should be a viable tool for $\mathrm{N}$ management.

Yield was positively correlated to $\mathrm{Ca}, \mathrm{pH}$, and CEC in 1997 (Table 4). Ping and Green (35) reported that cotton yield increased with increasing sand content and decreased with increasing clay content during the extremely dry growing season of 1998. Based on particle size analysis, soil samples collected at 55 of the 57 grid points measured in this study were classified as sandy loam. Correlations between yield and sand, silt, and clay content were not observed in the narrow range of textures reported here.

The ability of cotton to adapt to its environment can be expected to influence yield variability. However, the correlation of yield among years suggests that relative productivity remained somewhat constant across the three growing seasons of this study. To maximize production efficiency, it is necessary to determine what is limiting production in a particular part of a field. Fertilizers and pesticides can be applied as needed using variable rate technology (VRT). Furthermore, it is also possible to manage soil properties that are not amenable to VRT. For example, if yield is limited by insufficient water availability due to soil texture or organic 


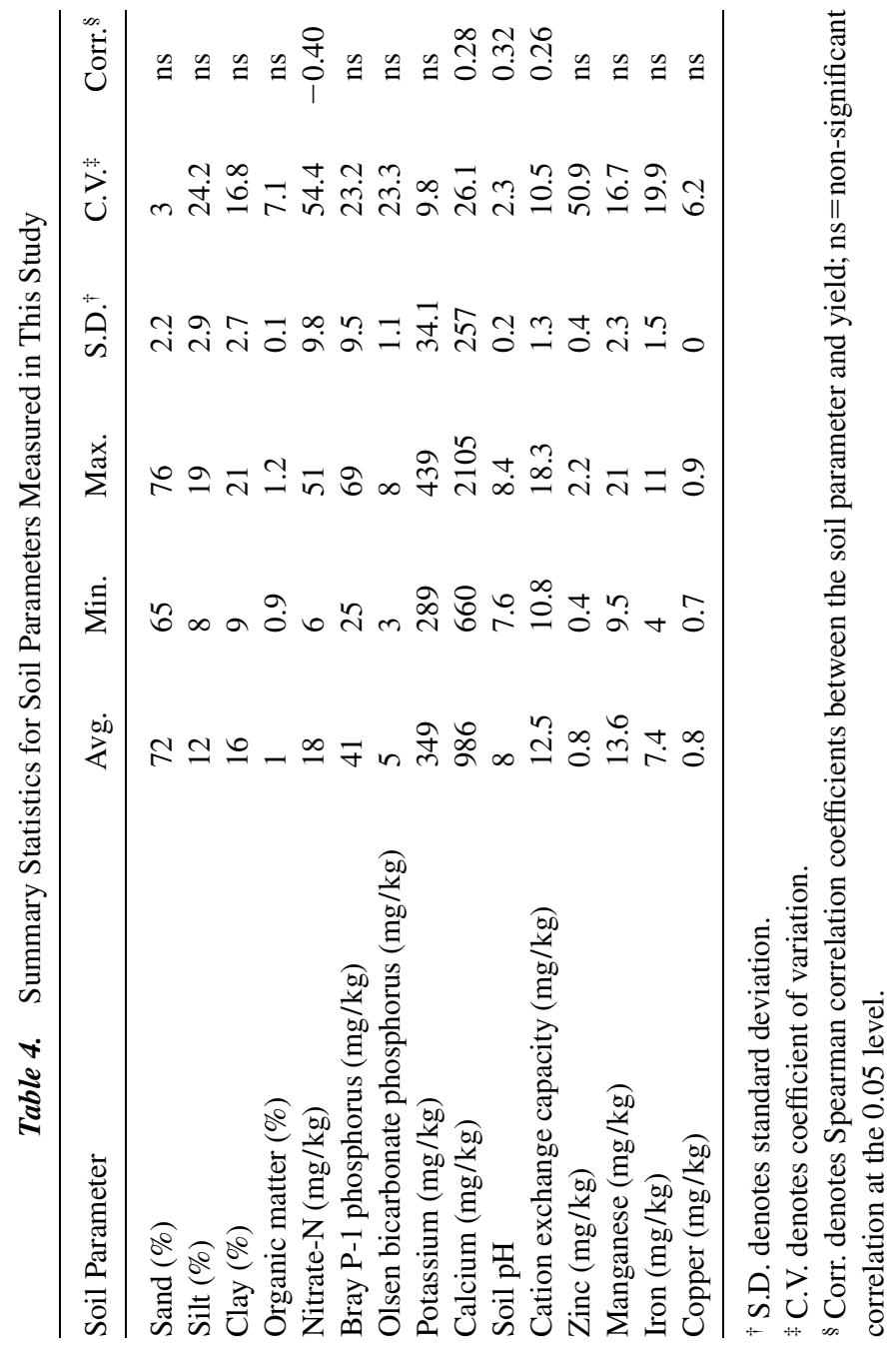


matter content at a point in a field, it may be possible to reduce inputs at that point; the amount of fertilizer applied and the seeding rate could be reduced. This could increase profitability by reducing inputs (i.e., production costs) of factors that are not limiting. Additionally, by maximizing inputs (increasing seeding or fertilizer rates) in areas of a field that are naturally more productive, yields may be increased. By utilizing an active crop scouting program during the growing season and identifying problematic areas, utilization of precision agriculture technologies for pesticide use may increase efficiency even more.

\section{CONCLUSIONS}

In general, highest variability was observed for lint yield and production of fruiting sites, and lowest variability was observed for lint quality parameters. The variability of cotton yield observed in this study is consistent with that reported for other common crops. Furthermore, the variability was correlated across growing seasons. Nitrate concentrations were highly variable, and yield was negatively correlated to $\mathrm{N}$ in 1997. This suggests that variable application of $\mathrm{N}$ may be a viable management option in the future. Yield was positively correlated to $\mathrm{Ca}$, $\mathrm{pH}$, and CEC in 1997. Gross revenues were quite variable, and this variability was due primarily to variability in yield. Although yield was correlated to production of fruiting sites each season, the exact cause for the yield variability observed in this study is not fully known. As suggested in other studies, it is likely that yield was influenced by a complex interaction of several factors. These factors could include irrigation efficiency, soil fertility, plant population, disease pressure, weed pressure, or insect pressure. Additional studies are underway to further determine factors influencing variability in yield and quality of cotton.

\section{ACKNOWLEDGMENTS}

This is contribution T-4-478 of the College of Agriculture and Natural Resources. Financial support for soil analyses was provided by the Potash and Phosphate Institute, and A\&L Plains Agricultural Laboratories, Inc., Lubbock, TX.

\section{REFERENCES}

1. Meredith, W.R., Jr. Agronomic factors and yield variability. In Proceedings of the Beltwide Cotton Conferences, Nashville, TN, Jan. 9-12, 1996. Dugger, P., Richert, D.A., Eds.; National Cotton Council of America: Memphis, TN, 1996; 180-184. 
2. Wilkerson, J.B.; Hart, W.E. Yield Sensing Technology in Cotton Harvest Applications. In Proceedings of the Beltwide Cotton Conferences, Nashville, TN, Jan. 9-12, 1996; Dugger, P., Richter, D.A., Eds.; National Cotton Council of America: Memphis, TN, 1996; 184-186.

3. Warrick, A.W.; Gardner, W.R. Crop Yield as Affected by Spatial Variations of Soil and Irrigation. Water Resour. Res. 1983, 19, 181-186.

4. Oosterhuis, D.M.; Rutledge, E.M.; Stutte, C.A.; Wullschleger, S.D.; Hampton, R.E.; Bell, C.R. In-Field Growth Variability. Arkansas Farm Res. 1991, 40(4), 9-10.

5. Bradow, J.M.; Davidonis, G.H.; Hinojosa, O.; Wartelle, L.H.; Pratt, K.J.; Pusateri, K.; Bauer, P.J.; Fisher, B.; Sassenrath-Cole, G.F.; Dastoor, P.H.; Johnson, A.; Landivar, J.A.; Locke, D.; Moseley, D. Environmentally Induced Variations in Cotton Fiber Maturity and Related Yarn and Dyed Knit Defects. In Proceedings of the Beltwide Cotton Conferences, Nashville, TN, Jan. 9-12, 1996; Dugger, P., Richter, D.A., Eds.; National Cotton Council of America: Memphis, TN, 1996; 1279-1284.

6. Grimes, D.W.; Yamada, H.; Dickens, W.L. Functions for Cotton (Gossypium hirsutum L.) Production from Irrigation and Nitrogen Fertilization Variables. I. Yield and Evapotranspiration. Agron. J. 1969, 61, 769-773.

7. Bradow, J.M.; Sassenrath-Cole, G.F.; Hinojosa, O.; Wartelle, L.H. Cotton Fiber Physical and Physiological Maturity Variation in Response to Genotype and Environment. In Proceedings of the Beltwide Cotton Conferences, Nashville, TN, Jan. 9-12, 1996; Dugger, P., Richter, D.A., Eds.; National Cotton Council of America: Memphis, TN, 1996; 1251-1254.

8. Nelson, W.L. The Effect of Nitrogen, Phosphorus, and Potash on Certain Lint and Seed Properties of Cotton. Agron. J. 1949, 41, 289-293.

9. Cassman, K.; Kerby, T.A.; Roberts, B.A.; Brouder, S.M. Reassessing Potassium Requirements of Cotton for Yield and Fiber Quality. In Proceedings of the Beltwide Cotton Conferences, Las Vegas, NV, Jan. 9-14, 1990; Brown, J.M., Richter, D.A., Eds.; National Cotton Council of America: Memphis, TN, 1990; 60-64.

10. Mulla, D.J. Mapping and Managing Spatial Patterns in Soil Fertility and Crop Yield: Soil-Specific Crop Management. In Proceedings of Soil-Specific Crop Management, Minneapolis, MN, April 14-16, 1992; Robert, P.C., Rust, R.H., Larson, W.E., Eds.; ASA, CSSA, SSSA: Madison, WI, $1993 ; 15-26$.

11. Vanden-Heuvel, R.M. The Promise of Precision Agriculture. J. Soil Water Cons. 1996, 51, 38-40.

12. Landivar, J.A.; Benedict, J.H. Monitoring System for the Management of Cotton Growth and Fruiting. Texas Ag. Exp. Sta. Bull. B02, Sept. 1996.

13. U.S. Dept. of Agriculture. The Classification of Cotton. Agricultural Hand- 
book 566. Agricultural Marketing Service, U.S. Dept. of Agriculture: Washington, DC, 1993.

14. Nelson, D.W.; Sommers, L.E. Total Carbon, Organic Carbon and Organic Matter. In Methods of Soil Analysis, Part 2, 2nd Ed.; Page, A.L., Miller, R.H., Keeney, D.R., Eds.; American Society of Agronomy: Madison, WI, 1982; 539-594.

15. Olsen, S.R.; Sommers, L.E. Phosophorus. In Methods of Soil Analysis, Part 2, 2nd Ed.; Page, A.L., Miller, R.H., Keeney, D.R., Eds.; American Society of Agronomy: Madison, WI, 1982; 416-418.

16. Thomas, G.W. Exchangeable Cations. In Methods of Soil Analysis, Part 2, 2nd Ed.; Page, A.L., Miller, R.H., Keeney, D.R., Eds.; American Society of Agronomy: Madison, WI, 1982; 159-165.

17. Lindsay, W.L.; Norvell, W.A. Development of a DTPA Soil Test for Zinc, Iron, Manganese and Copper. Soil Sci. Soc. Amer. J. 1978, 42, 421-428.

18. Mulvaney, R.L. Nitrogen-Inorganic Forms. In Methods of Soil Analysis; Bartols, J.M., Bigham, J.M., Eds.; American Society of Agronomy: Madison, WI, 1996; 1123-1184.

19. Gee, G.W.; Bauder, J.W. Particle Size Analysis. In Methods of Soil Analysis, Part 1, 2nd Ed.; Klute, A., Ed.; American Society of Agronomy: Madison, WI, 1986; 383-411.

20. Schulman, R.S. Statistics in Plain English with Computer Applications; Van Nostrand Reinhold: New York, 1992.

21. Little, T.M.; Hills, F.J. Agricultural Experimentation-Design and Analysis. John Wiley and Sons: New York, 1978.

22. Conover, W.J. Practical Nonparametric Statistics. John Wiley and Sons, Inc.: New York, 1971.

23. Ott, L. An Introduction to Statistical Methods and Data Analysis, 2nd Ed.; PWS Publishers: Boston, MA, 1984.

24. Hoelscher, K.; Ethridge, D.; Misra, S. Texas-Oklahoma Producer Cotton Market Summary 1997/98. Col. of Agric. Sc. and Nat. Res. Tech. Report 1998, CER-98-39.

25. SAS Institute. SAS User's Guide: Statistics, 5th Ed.; Statistical Analysis System Institute: Cary, NC, 1985.

26. Marani, A., and M. Horwitz. 1963. Growth and Yield of Cotton as Affected by the Time of a Single Irrigation. Agron. J. 1963, 55, 219-222.

27. Riney, J.B.; Best, E.C.; Krieg, D.R. Genetic and Environmental Factors Affecting Production and Retention of Fruiting Sites. In Proceedings of the Beltwide Cotton Conferences, New Orleans, LA, Jan. 6-10, 1997; Dugger, P., Richter, D.A., Eds.; National Cotton Council of America: Memphis, TN, 1997; $1385-1387$.

28. Sawan, Z.M.; Mahmoud, M.H.; Gregg, B.R. Effect of Foliar Application of 
Chelated Copper and Manganese on Yield Components and Fiber Properties of Egyptian Cotton (Gossypium barbadense). J. Agric. Sci. 1993, 121, 199-204.

29. Jenkins, J.N.; McCarty, J.C., Jr.; Parrott, W.L. Fruiting Efficiency in Cotton: Boll Size and Boll Set Percentage. Crop Sci. 1990, 30, 857-860.

30. Guinn, G. Cause of Square and Boll Shedding in Cotton. USDA-ARS Tech. Bull. 1672. U.S. Government Printing Office: Washington, DC, 1982.

31. Guinn, G.; Mauney, J.R. Fruiting of cotton. II. Effects of Plant Moisture status and Active Boll Load on Boll Retention. Agron. J. 1984, 76, 94-98.

32. Gipson, J.R.; Joham, H.E. Influence of Night Temperature on Growth and Development of Cotton (Gossypium hirsutum L.). II. Fiber Properties. Agron. J. 1968, 60, 296-298.

33. DeLanghe, E.A.L. Lint Development. In Cotton Physiology; Mauney, J.R., Stewart, J.M., Eds.; The Cotton Foundation: Memphis, TN, 1986; 325-349.

34. Munro, J.M. Cotton, 2nd Ed.; John Wiley and Sons, Inc.: New York, 1987.

35. Ping, J.; Green, C.J. Spatial Analysis of Agronomic Properties in Two Production Cotton Fields in West Texas. In Proceedings of the Beltwide Cotton Conferences, Orlando, FL, Jan. 3-7, 1999; Dugger, P., Richter, D.A., Eds.; National Cotton Council of America: Memphis, TN, 1999.

36. Pennington, D. In-Field Yield Variability of Cotton. In Proceedings of the Beltwide Cotton Conferences, New Orleans, LA, Jan. 3-8, 1988; Brown, J.M., Richter, D.A., Eds.; National Cotton Council of America: Memphis, TN, 1988; 518-519.

37. Johnson, R.M.; Bradow, J.M.; Bauer, P.J.; Sadler, E.J. Spatial Variability of Cotton Fiber Properties. In Proceedings of the Beltwide Cotton Conferences, San Diego, CA, Jan. 5-9, 1998; Dugger, P., Richter, D.A., Eds.; National Cotton Council of America: Memphis, TN, 1998; 1465-1466.

38. Johnson, R.M.; Bradow, J.M.; Bauer, P.J.; Sadler, E.J. Influence of Soil Spatial Variability on Cotton Fiber Quality. In Proceedings of the Beltwide Cotton Conferences, Orlando, FL, Jan. 3-7, 1999; Dugger, P., Richter, D.A., Eds.; National Cotton Council of America: Memphis, TN, 1999; 13191320.

39. Karlen, D.L.; Sadler, E.J.; Busscher, W.J. Crop Yield Variation Associated with Coastal Plain Soil Map Units. Soil Sci. Soc. Am. J. 1990, 54, 859-865. 


\section{Request Permission or Order Reprints Instantly!}

Interested in copying and sharing this article? In most cases, U.S. Copyright Law requires that you get permission from the article's rightsholder before using copyrighted content.

All information and materials found in this article, including but not limited to text, trademarks, patents, logos, graphics and images (the "Materials"), are the copyrighted works and other forms of intellectual property of Marcel Dekker, Inc., or its licensors. All rights not expressly granted are reserved.

Get permission to lawfully reproduce and distribute the Materials or order reprints quickly and painlessly. Simply click on the "Request

Permission/Reprints Here" link below and follow the instructions. Visit the U.S. Copyright Office for information on Fair Use limitations of U.S. copyright law. Please refer to The Association of American Publishers' (AAP) website for guidelines on Fair Use in the Classroom.

The Materials are for your personal use only and cannot be reformatted, reposted, resold or distributed by electronic means or otherwise without permission from Marcel Dekker, Inc. Marcel Dekker, Inc. grants you the limited right to display the Materials only on your personal computer or personal wireless device, and to copy and download single copies of such Materials provided that any copyright, trademark or other notice appearing on such Materials is also retained by, displayed, copied or downloaded as part of the Materials and is not removed or obscured, and provided you do not edit, modify, alter or enhance the Materials. Please refer to our Website User Agreement for more details.

\section{Order now!}

Reprints of this article can also be ordered at http://www.dekker.com/servlet/product/DOI/101081CSS100103012 